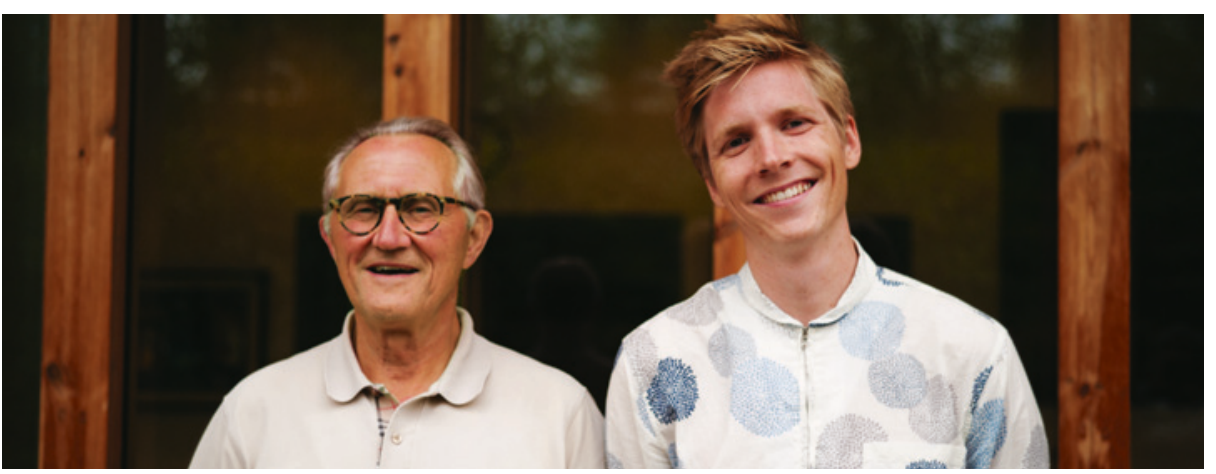

Geir W. Jacobsen og Tormod Rogne. Foto: May Karin Dyrendahl

\title{
Glukosetoleranse og fødselsvekt
}

Gravide med høy glukosetoleranse kan ha økt risiko for å føde barn med lav fødselsvekt.

Forskerlinjestudent Tormod Rogne har studert hvordan ulik stigning i blodsukkernivå etter glukosebelastning i svangerskapet er assosiert med fosterets vekst og fødselsvekt. Resultatene er nylig publisert i Acta Obstetricia et Gynecologica Scandinavica. Dette er Rognes første publikasjon.

Studien er basert på et materiale fra 1980årene. Det omfattet 855 gravide, hvorav $70 \%$ på bakgrunn av kjente faktorer og tidligere svangerskap hadde økt risiko for å få barn med lav fødselsvekt. Kvinnene gjennomgikk en oral glukosetoleransetest i uke 37, der blodsukkernivået ble målt fastende og to timer etter et inntak av 75 g glukose. De ble inndelt i tre grupper basert på blodsukkernivåstigning - lav stigning, dvs. under 10-prosentilen ( $\mathrm{n}=103)$, høy stigning, dvs. over 90-prosentilen $(\mathrm{n}=91)$, stigning mellom disse ytterpunktene $(n=661)$. Fostervekst og avvik fra estimert fostervekt ble vurdert med ultralydunders $ø$ kelse i uke 25 , 33 og 37. Fødselsvekt og øvrige antropometriske målinger ble notert etter fødselen.

Mange av vekstvariablene for fostre og nyfødte født av kvinner i gruppen med lav blodsukkernivåstigning var signifikant lavere enn i gruppen med middels stigning, mens de var tilsvarende høyere i gruppen med høy stigning enn i gruppen med middels stigning. Fosterveksten fra uke 25 til uke $37 \mathrm{i}$ gruppen med lav stigning var mindre enn $i$ de andre gruppene.

- Siden $70 \%$ av kvinnene hadde en noe forhøyet risiko for å føde lavvektige barn, er det vanskelig å si om man vil se tilsvarende effekt $i$ en generell populasjon gravide, sier Tormod Rogne. - Vårt mål på glukosetoleranse var nokså grovt. Vi mener likevel det er interessant at kvinner som har for høy glukosetoleranse i svangerskapet, kan ha økt risiko for å føde lavvektige barn, sier Rogne.
Ordforklaringer

Glukosetoleranse: Evnen til å gjenopprette normalt blodsukkernivå etter en standardisert sukkerbelastningsprøve.

Antropometriske målinger: Målinger av menneskekroppen. Har som oftest med størrelse, vekt og proporsjoner å gjøre.

Estimert fostervekt: Beregnet vekt av fosteret basert på ultralydmålinger av fosterets hode, mage og lår.
- I denne studien var vi spesielt interessert i kvinner med lav stigning i blodsukkernivå. Siden man i dag primært er opptatt av å fange opp poten-siell diabetes, har kvinner i denne enden av spekteret for glukosetoleranse vært ansett som normale. I fremtidige studier bør man benytte mer presise mål på glukosetoleranse og insulinresistens enn $i$ vår studie, som altså var basert på data fra 1980-årene, og vurdere disse variablene flere ganger i løpet av svangerskapet, sier Rogne.

\section{Skandinavisk samarbeid}

Artikkelen springer ut fra en forskningsgruppe innen perinatal epidemiologi ved Det medisinske fakultet, Norges teknisknaturvitenskapelige universitet, hvor Tormod Rogne er forskerlinjestudent. Geir W. Jacobsen, sisteforfatter på artikkelen, er professor ved Institutt for samfunnsmedisin og daglig leder av Scandinavian Small for Gestational Age-studien. Dette er en stor, prospektiv multisenterstudie med data om svangerskap og fødsler i Bergen, Trondheim og Uppsala i perioden 1986-88. Målet med studien var å studere fostervekst, perinatalt utfall og tendensen til å få et nytt negativt utfall i påfølgende svangerskap.

Materialet fra den opprinnelige studien er utgangspunktet for Rognes forskerlinjearbeid og senere doktorgradsarbeid. Doktorgradsarbeidet vil også inkludere en studie om fostervekstens betydning for hjerneutvikling $\mathrm{og}$ kognisjon og en systematisk oversikt om sammenhengen mellom blodkonsentrasjonen av vitaminer og fødselsvekt.

\section{Hanne Støre Valeur}

Tidsskriftet

\section{Litteratur}

1. Rogne T, Jacobsen GW. Association between low blood glucose increase during glucose tolerance tests in pregnancy and impaired fetal growth. Acta Obstet Gynecol Scand 2014. E-publisert 26.2.
Artikkelen ble e-publisert 26.2. 2014 i Acta Obstetricia et Gynecologica Scandinavica 